\title{
Aharon Appelfeld: Mitteleuropa em língua hebraica
}

\author{
Luis S. Krausz - USP
}

Resumo: Obliterado pelo genocídio, o mundo judaico da Europa Central ganha uma surpreendente sobrevida na literatura de Aharon Appelfeld, criada na contra-mão do projeto sionista de ruptura com o passado diaspórico. Por meio da recriação da aura e dos rastros do mundo de sua origem, Appelfeld preserva do esquecimento uma episteme, um conjunto de conceitos estruturantes da cultura dos judeus assimilados e germanizados do antigo Império Habsburgo, que se mantiveram apegados à língua e à cultura alemãs, permanecendo inconscientes das ameaças crescentes que se erguiam neste universo que, ainda uma geração antes de Appelfeld, fora o sinônimo da civilização.

Palavras-chave: Literatura hebraica; Monarquia Habsburga; Mitteleuropa

Em Shop Talk, livro baseado em uma série de encontros com escritores judeus do século 20, o norte-americano Philip Roth afirma que o escritor hebraico Aharon Appelfeld leva a um paroxismo o conceito de desterritorialização. Este conceito estrutura de maneira exemplar a obra de um autor nascido na Romênia, criado num lar de língua alemã, e que construiu em Israel e em língua hebraica um corpus ficcional no qual os rastros e a aura da cultura germânica da monarquia habsburga - e a atração que esta cultura exerceu sobre os judeus da Europa Central - são um tema central.

Nascido em Czernowitz, que até 1918 fora o principal pólo de difusão da cultura alemã nos confins orientais do Império Austro-Húngaro, Appelfeld era filho de pais judeus voltados para os parâmetros da sociedade burguesa do século 19 - como, aliás, outros de seus concidadãos que contribuíram de maneira destacada para a literatura em língua alemã do século 20, dentre os quais são incontornáveis, dentre tantos outros, os nomes de Paul Celan, Franz Kafka e Rose Ausländer.

Appelfeld sobreviveu à Shoá, ainda criança, escondendo-se nas florestas da Romênia e da Ucrânia e, aos 14 anos de idade, emigrou para Israel, onde aprendeu o idioma hebraico. Sua obra é, em grande parte, uma reconstrução, na língua do Estado Judeu, do universo judaico da Mitteleuropa, bifurcado entre a filiação à tradição judaica, e em especial à tradição do hassidismo, e a fascinação pela cultura laica e germanizada do século 19, que atraiu os judeus desta região, especialmente aqueles pertencentes às camadas sociais mais elevadas.

Obliterado pelo genocídio, este mundo bipartido ganha uma surpreendente sobrevida na literatura de Appelfeld, criada na contra-mão do projeto sionista de ruptura com o passado diaspórico e de construção de uma nova identidade israelense, independente do passado judaico recente na Europa. Por meio da apropriação e da recriação da aura e dos rastros de seu mundo familiar, varrido da face do mundo, Appelfeld reconstrói, em Israel e em língua hebraica, não só sua história pessoal, mas preserva do esquecimento uma episteme, um conjunto de conceitos estruturantes de um modo de ser e de pensar que 
desapareceu de suas terras de origem, espalhando-se pelos quatro cantos do mundo ou simplesmente perecendo sob o aparelho exterminador nazista, nos anos 1930 e 1940.

A integração dos judeus da Europa Central numa cultura de molde secular, fundamentada no racionalismo e no Iluminismo, é um processo que se desenrola ao longo de todo o século 19, em decorrência, de um lado, da crise econômica e espiritual das aldeias e guetos judaicos e, de outro lado, da implementação de uma política que visava tornar esses judeus cidadãos "úteis" dos países em que viviam - em especial a Prússia e o Império Austro-húngaro. Ao longo de todo o século 19, todos os tipos de legislações discriminatórias foram pouco a pouco revogados nesses países, de maneira a permitir que este grupo antes relegado, no mais das vezes, às margens da sociedade, se integrasse no corpo de cidadãos, convivendo como iguais - ou quase-iguais - com seus vizinhos de outras origens étnicas e filiações religiosas.

Mesmo depois do desmembramento do Império, em 1918, os judeus germanizados da Mitteleuropa se mantiveram profundamente apegados à língua e à cultura alemãs, permanecendo inconscientes das ameaças crescentes que se erguiam exatamente neste universo. Para eles, a Alemanha permanecia como sinônimo de civilização e de salvação da estreiteza e do declínio do universo judaico tradicionalista, ancorado em conceitos e em paradigmas herdados da Idade Média. A Alemanha, a língua alemã e os costumes alemães eram sinônimos da Europa e da passagem para a modernidade, enquanto que os costumes tradicionais judaicos se tornavam a cada tanto mais repelentes para uma classe social que se habituava à vida nas grandes cidades e se afinava com os parâmetros de um cosmopolitismo oitocentista.

Este cosmopolitismo, e esta visão de mundo ancorada nas idéias do Iluminismo e da Bildung, no entanto, tornou-se, a partir do término da $1^{\mathrm{a}}$. Guerra Mundial, a cada tanto mais fictício, ao mesmo tempo em que, para os judeus emancipados e parcialmente assimilados, a identidade judaica se tornara algo tênue e muitas vezes mal compreendido. Como afirma Appelfeld:

Hitler forçou esses judeus assimilados a se tornarem judeus. Aqueles que tiveram o infortúnio de permanecer lá, (na Europa) passaram os últimos dias de suas vidas nos campos junto com os judeus da Europa do Leste, que eles haviam tentado evitar durante todas as suas vidas. E até mesmo aqueles que vieram para Israel, não se sentiam felizes entre os judeus. A luta e a ambivalência com respeito à própria identidade fizeram com que eles se voltassem para dentro de si mesmos, se isolassem do que estava à sua volta, freqüentemente tornando-se seus próprios piores inimigos. ${ }^{1}$

Ao contrário do que poderia parecer à primeira vista, Appelfeld demonstra, em sua literatura, uma grande afinidade para com esses judeus assimilados que, no período entreguerras, viram desaparecer rapidamente o solo sobre o qual haviam lançado os fundamentos de suas existências e de suas identidades culturais. Na mesma conversa com Philip Roth citada acima, ele afirmou:

Os judeus assimilados construíram uma estrutura de valores humanistas e contemplavam o mundo externo a partir dessa estrutura. Estavam convictos de que não eram mais judeus e que tudo aquilo que se aplicava aos 'judeus' não se aplicava a eles. Essa confiança estranha os transformou em criaturas cegas, ou quase cegas. Sempre adorei os judeus assimilados, porque era neles que o 
caráter judaico, e também talvez o destino judaico, estava concentrado com maior força. ${ }^{2}$

A obra literária de Appelfeld dedica-se, em grande parte, a reconstruir esse universo desaparecido dos judeus assimilados da Europa Central, execrados pelos nacionalismos europeus tanto quanto pelo nacionalismo sionista e cujo destino parece ter sido um exílio irremediável, em todas as partes do mundo.

Esse destino faz pensar nas idéias místicas do cabalista hispânico Isaac Luria, que desenvolve uma teoria a respeito da transmigração das almas e dos diversos graus do exílio. Segundo a teoria luriânica, o mais horrendo dos destinos é o daquelas almas denominadas de "nuas", que não são destinadas ao inferno nem tampouco à reencarnação, mas permanecem sobre o abismo do exílio em seu estado puro. Gershom Scholem, com quem Aharon Appelfeld teve contato durante seus anos de estudante na Universidade Hebraica de Jerusalém, descreve este paroxismo do exílio com as seguintes palavras: "O ser inteiramente privado de lar torna-se (...) um conceito limite de todas as catástrofes morais e espirituais." 3

Uma boa parte da produção ficcional de Appelfeld é um mergulho no universo imediatamente anterior à constelação desse "exílio dos exílios" que atingiu aqueles membros da geração de seus pais que sobreviveram à catástrofe, isto é, é uma reconstrução do universo do qual o escritor foi arrancado aos oito anos de idade. E esta reconstrução se dá por meio de um paciente colecionismo, que reúne memórias esparsas e encontros esporádicos numa série de romances cujos limites são nebulosos e que constituem, em seu conjunto, uma épica de um mundo desaparecido.

Os conceitos benjaminianos de Spur e Aura são elementos constitutivos fundamentais nesse empreendimento de reconstrução literária, por meio dos quais se potencializam os espectros do mundo declinante dos judeus germanizados no período entre-guerras.

Ao escrever sobre o romance Adrienne Mesurat, do escritor franco-norte-americano Julian Green, Benjamin propõe uma definição para o conceito de Spur: seria a saudade de um mundo cujo desaparecimento ele percebe. Benjamin persegue, na literatura francesa, rastros do passado, descobre ruínas e parte em busca dos últimos remanescentes de uma época que se encerrou. Os romances de Green desenham o declínio de um mundo e testemunham a persistência dos rastros desse mundo na literatura, bem depois do declínio e do desaparecimento deste mundo - um mundo pertencente à "era mágica". Seu interesse é por textos de Green nos quais se articula este desenvolvimento, ou nos quais desponta o limiar de uma nova era, cujo alvorecer se revela por meio das ruínas daquilo que ficou para trás.

Da mesma forma que a literatura de Green, os romances Austro-húngaros de Appelfeld buscam capturar a aura de um mundo mágico que declinou e desapareceu, e que é, a um só tempo, o mundo da infância do escritor e o estertor do universo dos judeus germanizados das antigas terras da coroa habsburga. Ele contempla as ruínas deste tempo e deste lugar, obliterados pela catástrofe, a partir de um ponto de vista e de um território que lhe são diametralmente opostos: a realidade das primeiras décadas do Estado de Israel, período em que a ideologia dos pioneiros do sionismo e do coletivismo exercia um papel preponderante, quase hegemônico, ao mesmo tempo em que triunfava a idéia de que uma ruptura com todo o legado diaspórico se fazia necessária para um renascimento e uma reinvenção do povo judeu.

A ideologia dos pioneiros da criação do Estado de Israel tinha como fulcro, já desde a sua origem, no fim do século 19, a criação do "novo Hebreu" - uma figura idealizada a partir de modelos derivados do romantismo alemão tanto quanto do socialismo, central à 
ideologia sionista tanto quanto ao gênero literário denominado de Eretz-israelense que, por sua vez, exerceu um papel determinante no sentido de moldar o consenso social dentre os imigrantes judeus na Palestina Britânica, no período imediatamente anterior à criação do Estado de Israel, assim como nos anos de cristalização do jovem estado.

Este modelo, baseado nas estruturas coletivas de agricultura, nos modelos coletivos de urbanização e numa ideologia socialista de caráter uniformizante, tomava como pressupostos básicos, de um lado, uma ruptura total com o passado judaico diaspórico, visto como corrupto e, de outro, a adoção irrestrita do idioma hebraico em substituição a todos os idiomas trazidos das terras de origem dos imigrantes.

Tencionava-se varrer os rastros de uma história percebida como catastrófica para inaugurar, à força se necessário, um novo período na existência coletiva do povo judeu o período que é conhecido na literatura profético-messiânica como Kibutz Galuyot ou seja, a reversão de todos exílios.

A resistência de Appelfeld a este projeto uniformizante deu-se, num primeiro momento, de maneira silenciosa, quase secreta. Originário de um lar de língua alemã, mas dissociado deste idioma pelos anos em que vagou, sozinho, pelas florestas da Ucrânia e da Rússia para escapar dos nazistas e de seus aliados, Appelfeld passou a estudar numa escola agrícola logo de sua chegada à Palestina Britânica, em 1946. Não obstante, lia todos os livros alemães que pudesse encontrar, de maneira persistente e em segredo, provocando a indignação de seus professores.

Conforme ele narra em A Table for One, volume autobiográfico lançado em 2004, nestes livros ele encontrava alguns rastros e as pistas do lar do qual foi arrancado aos oito anos de idade. Mas foi na década de 1950, depois de concluir a escola agrícola e o serviço militar, que ele encontraria o que denominou de umbral de seu lar perdido: os cafés de dois bairros de Jerusalém - Rehavia e a Moshava Germanit - onde se reuniam imigrantes de sua extração. Em busca das pistas do mundo em que nasceu, ele passa, a partir daí, longas horas nesses cafés onde escuta as conversas dos judeus de língua alemã do antigo Império Habsburgo. Observa seus gestos e expressões faciais, suas maneiras à mesa, seus gostos e predileções para, aos poucos, recompor de alguma forma, dentro de si e em seus livros, aquilo que o tempo e a guerra, a distância e os nacionalismos se empenharam em destruir. Ali encontra emanações tardias de uma paisagem humana desaparecida, como as luzes de sóis extintos há milênios que continuam a transitar pelo espaço sideral.

Aqueles sobreviventes que se reúnem ali conjuram imagens espectrais daquelas almas e cidades que foram reduzidas a pó e a aura de seu mundo constela-se como "aparição singular de uma distância” (Die Definition der Aura als ,einmalige Erscheinung einer Ferne, so nah sie sein mag") 4 desvinculada do mundo que lhe deu origem, como abstração e quintessência.

A condição existencial desses imigrantes continuava a ser a condição de exilados, ainda que vivessem nas terras que, segundo a ideologia do sionismo tanto quanto das especulações místicas e filosóficas da Idade Média, representavam o fim do exílio. Assim, Appelfeld escreve: "Esta essência era corporificada por estes emigrantes, que falavam o alemão habsburgo; que haviam sido arrancados das suas terras de nascença e agora se encontravam perdidos em seu lar nacional"5. Dentre esses exilados, ele encontraria os rastros e a aura do mundo desaparecido de sua infância: "O Império Austro-Húngaro permanecia ali, no Café Peter, e os sobreviventes pairavam como sombras..."

Por meio do contato com esses imigrantes Appelfeld descobriu que seu lar não era o lar da revolução hebraica, da qual até então ele lutava para tomar parte, mas o não-lugar dos 
emigrantes - lugar que, a partir daí, ele passa a reconstruir numa literatura atenta às singularidades de um mundo desaparecido. Em seus romances austro-húngaros, ele recompõe a aura daquilo que foi obliterado pelo genocídio, por meio de uma paciente coleta de fragmentos, de rastros e de ecos que remetem a atmosferas, expressões, desejos e questões existenciais próprias de um mundo extinto.

Esta reunião de memórias esparsas, muitas vezes desconexas, é um procedimento que também retoma um conceito da cabala de Isaac Luria, nominalmente o conceito de Tikkun, reparação ou restituição daquilo que foi rompido, ou seja, a reunião dos fragmentos gerados por aquilo que Luria denominou de schebirat ha-Kelim ou o "rompimento dos vasos". Cabe lembrar que este é um conceito discutido em profundidade por Gershom Scholem, em Die jüdische Mystik in ihre Hauptströmungen e que, como já foi dito, Scholem foi professor de Appelfeld na Universidade Hebraica de Jerusalém.

O caráter colateral desses fragmentos torna os personagens secundários e as observações marginais, nesses romances austro-húngaros de Appelfeld, tão importantes quanto os protagonistas e o enredo principal. Nas emoções menores, nos objetos secundários, a aura deste mundo desaparecido se manifesta com maior força: Appelfeld é praticante de uma literatura onde não há lugar para a grandiloqüência nem para o espetacular. Nos gestos miúdos, nos detalhes aparentemente irrelevantes manifestam-se com maior clareza aquelas essências de uma paisagem humana obliterada que ele se empenha em conservar, resistindo à "revolução cultural" do nacionalismo judaico para, ao mesmo tempo, escavar as ruínas do que foi demolido pelo genocídio.

Esta arqueologia do pós-guerra é empreendida na contra-mão da agenda ideológica do Estado Judeu: Appelfeld vasculha os escombros esquecidos da Europa Central judaica em busca de objetos de culto perdidos, que possam reconduzi-lo a uma infância interrompida e que o deixam vislumbrar, outra vez, as moradas carbonizadas e ouvir as vozes dos que foram reduzidos a cinzas.

Os fragmentos e pistas dispersos que ele encontra no âmbito das lembranças pessoais ou em seu convívio com emigrantes e sobreviventes constroem uma literatura que nasce de um esforço anti-histórico, ao mesmo tempo em que a história é percebida como acumulação de escombros. Em vez de construir mundos que possam servir como paradigmas e modelos para a sociedade nascente em meio à qual vive, seu objetivo como escritor é dar um sentido a esses fragmentos, cuja urdidura redesenha a imagem do mundo de onde foram arrancados.

Seus romances austro-húngaros são, por isso, como uma reunião de cacos que deixam adivinhar os contornos do vaso de que um dia fizeram parte, ainda que haja nessas reconstruções mais lacunas do que espaços preenchidos.

Concisão e reticência são, aqui, recursos estéticos deliberados que não apenas delimitam mas destacam os âmbitos restritos e imperfeitos de cada fragmento, de maneira que a reconstrução nunca se pretenda perfeita: também as ruínas de templos e esculturas da Grécia arcaica se tornariam patéticas se as partes vazias de suas formas, desaparecidas com o tempo, fossem preenchidas por materiais sintéticos. Pois é da natureza dos escombros servirem, também, como memorial e testemunho da própria destruição.

Neste sentido, a literatura anti-histórica de Appelfeld se torna, também, uma literatura de testemunho, em que a destruição é denunciada por sua imagem invertida, isto é, pela reunião de fragmentos e de pistas. Seu lugar único na literatura hebraica é o de um outsider que dá continuidade, em Israel, a um destino peculiar do judaísmo diaspórico. 


\begin{abstract}
The traces and aura of the vanished world of Central European Jewry have been granted a surprising afterlife in Aharon Appelfeld's Hebrew novellas and short stories, which have been created against the background of the Zionist project of rupture with the Diasporic past. Appelfeld has thus preserved the culture and world-view of the assimilated and germanized Jews from the Habsburg Empire, who remained attached to German cuture and language and who refused to believe that their destruction would come from the very same universe they considered to be synonimous with the concept of civilization.
\end{abstract}

Keywords: Hebrew Literature; Habsburg Empire; Mitteleuropa

\title{
Referências Bibliográficas
}

APPELFELD, Aharon. The Story of a Life. Nova York: Schocken, 2004.

BENJAMIN, Walter. Illuminationen - Ausgewählte Schriften. Frankfurt: Suhrkamp Verlag, 1977

ROTH, Philip. Entre Nós. São Paulo: Companhia das Letras, 2008.

SCHOLEM, Gershon. Die jüdische Mystik in ihren Hauptströmungen, Zurique: Rhein Verlag, 1957

\section{Notas}

${ }^{1}$ APPELFLD. The story of a life, p. 56

${ }^{2}$ ROTH. Entre nós, p. 39

${ }^{3}$ SCHOLEM. Die jüdische Mystik in ihren Hauptströmungen, p. 274

${ }^{4}$ BENJAMIN. Illuminationen, p.143

${ }^{5}$ APPELFLD. The story of a life, p. 13.

${ }^{6}$ APPELFLD. The story of a life, p. 64. 